\title{
Surto de brucelose no oeste do Paraná: relato de dois casos
}

\author{
Hannusch, D.C.; Mendonça, J.L.; Woytovetch, C.A.; Rossi, F.S.; Lopes, L.M.; \\ Kunzler, C.C.;
}

Apresentador: Juliana Leme Mendonça

\section{Resumo}

Introdução: A brucelose é uma zoonose causada por bactérias do gênero Brucella transmitida pelo contato com fluidos de animais infectados, ingesta de alimentos contaminados ou inalação de aerossóis. Considerada pela Organização Mundial de Saúde como doença emergente e agente potencial para bioterrorismo, esta doença ocupacional tem prevalência subestimada pelo quadro clínico ser inespecífico, não ter notificação compulsória, exceto em casos de surtos, e pela inadequação diagnóstica e terapêutica desta patologia, muitas vezes pouco suspeitada. Relato de Caso: A.A.F., masculino, 51 anos, residente de zona rural em Foz do Iguaçu- PR, criador de gado. Em outubro de 2012 diagnosticado brucelose em animais de sua propriedade e vizinhos, que foram sacrificados. Realizada busca por humanos sintomáticos, o paciente referia: febre, fadiga, sudorese, anorexia, emagrecimento, cefaleia, mialgia e artralgia em membros há cerca de um mês. Solicitado sorologia para brucelose IgM, Rosa Bengala e Protein Chain Reaction (PCR), todos reagentes. Iniciado tratamento com doxiciclina 100 mg 12/12 horas + rifampicina $300 \mathrm{mg} \mathrm{12/12} \mathrm{horas}$ por 42 dias, prolongados por mais 18 dias pela manutenção dos sintomas e da sorologia reagente. Persistia com IgM reagente e Rosa Bengala positivo, sendo tratado por mais 60 dias. Manteve as mesmas queixas, exames após segundo tratamento: $\operatorname{IgM}$ indeterminado, Rosa Bengala e PCR reagentes. Indicado tratamento por 6 meses com doxiciclina + rifampicina, coletadas 5 hemoculturas. $\mathrm{O}$ paciente continua em acompanhamento médico. Paciente A.S.D., masculino, 23 anos, habita zona rural de Foz do Iguaçu-PR, criador de gado, portador de diabetes melitus tipo 1 sem adesão ao tratamento. Identificado astenia e linfonodomegalia inguinal esquerda. Exames Rosa Bengala e Brucelose IgM reagentes. Tratado com doxicilina e rifampicina por 42 dias. Exames de controle Rosa bengala positivo e Brucelose IgM não reagente. Novo tratamento

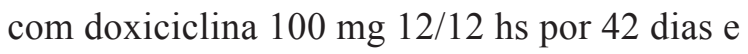
gentamicina $160 \mathrm{mg} /$ dia por 14 dias. Novos exames com negativação sorológica. Mantém acompanhamento ambulatorial sem sintomas. Conclusão: A brucelose é uma zoonose de distribuição universal e acarreta problemas sanitários e prejuízos econômicos vultosos por acometer rebanhos e ser de importante morbidade ao ser humano. O Brasil não possui uma rede estruturada na saúde pública para diagnóstico e tratamento desta doença, assim se faz relevante a disseminação do conhecimento dessa patologia.

\section{Referência:}

Hannusch, D.C.; Mendonça, J.L.; Woytovetch, C.A.; Rossi, F.S.; Lopes, L.M.; Kunzler, C.C.;. Surto de brucelose no oeste do Paraná: relato de dois casos. In: II Congresso Brasileiro de Medicina Hospitalar - II CBMH [= Blucher Medical Proceedings, vol.1, num.5] São Paulo: Editora Blucher, 2014. p.92

DOI 10.5151/medpro-II-cbmh-091 